\title{
EFFECT OF WOUNDING, AUXINS AND CINNAMON EXTRACT ON THE ROOTING AND VEGETATIVE GROWTH CHARACTERISTICS OF BOTTLE BRUSH PLANT (MELALEUCA VIMINALIS L.) CUTTINGS
}

\author{
Raghad L. Hameed and Asmaa M. Adil \\ Department of Horticulture and Landscaping, College of Agriculture and Forestry, University \\ of Mosul, Mosul, Iraq
}

\begin{abstract}
This study was conducted in the green house of the Department of Horticulture and Landscape Design, College of Agriculture and Forestry, Mosul University, Iraq to study the effect of wounding process and the rooting solutions of IBA and NAA in addition to cinnamon extract (cin.); C1 (0), C2 (750 IBA + 750 NAA $\left.\mathrm{mg} \mathrm{L}^{-1}\right)$, C3 (1500 IBA + 1500 NAA mg L $\left.{ }^{-1}\right)$, C4 (750 IBA + 750 NAA mg L ${ }^{-1}+2$ mg $100 \mathrm{ml}^{-1}$ cin.), C5 (750 IBA + $750 \mathrm{NAA} \mathrm{mg} \mathrm{L}^{-1}+$ $4 \mathrm{mg} 100 \mathrm{ml}^{-1}$ cin.), C6 (2 mg $100 \mathrm{ml}^{-1}$ cin.) and C7 (4 mg $100 \mathrm{ml}^{-1}$ cin.). In quick-dip method, the median cutting was used for this study. The experiment was carried out using the randomized complete block design (RCBD) with 3 replicates and 8 cuttings per repeater $(3 \times 2 \times$ $7)$. Data were analyzed using SAS. The results showed that wounding both the rooting rate as well as the length of vegetative growth. The control treatment gave the highest value as has also been observed that non-treatment of auxin induced in the leaves number and caused a significant increase in the studied properties compared with the treatment of unwounded cuttings.
\end{abstract} Scientific J. Flowers \& per se had no effect on rooting rate, length of vegetative growth and Ornamental Plants, the number of leaves. Whereas, solution C4 was the best among the 6(2):105-111(2019). other rooting solutions when coupled with wounding, which increased

Received:

9/5/2019

Accepted:

26/5/2019

Key words: Bottle brush, IBA, NAA, cinnamon extract, Melaleuca viminalis $\mathrm{L}$.

\section{INTRODUCTION}

The Melaleuca viminalis L. (synonym: Callistemon viminalis L.) is classified as one of the types of ornamental trees. It is called the bottle brush because of its red flowers, resemble a glass bottle brush. It is a small, evergreen tree. The leaves are narrow and opposite. When rubbed by hand, it gives a lemon scent. Vegetative propagation is one of the most important methods used in plant multiplication. The formation and appearance of transverse roots of cell division are attributed to the growth areas of the cambium cells (Abu Zeid, 2002). Growth regulators are considered to be one of the factors that promote the formation of Adventitious roots. Auxins are hormones that activate root formation on the stem and reveal lateral buds. Synthetic auxins like indole butyric acid (IBA) and naphthalene acetic acid (NAA) have proven to effectively stimulate the formation of roots on cuttings when applied exogenously (Ibrahim and Muhammad, 1991). The selection of the type of auxin, concentration and appropriate treatment method are necessary for the success of rooting (Salman, 1988). Recently, 


\section{Raghad L. Hameed and Asmaa M. Adil}

other natural materials have been used as alternatives to promote rooting and these materials include in honey and yeast and also extracts of some plants, such as ginger, licorice and cinnamon. Cinnamon is one of the most important medicinal plants, rich in active compounds, containing $4 \%$ pilot oil and the most important components of this oil are cinnamon aldehyde, cinnamic acid, cinnamyl alcohol, cinnamyl acitate, eugeuol, tannin and minerals (Gunjan and Anart, 2009). Saladdin (2015), in a study carried out on the cutting of the tree Melaleuca viminalis, where mechanical operations were used (without wounding, wounding and girdling), noted that the wounding process had a significant effect on the percentage of rooting and on root length (36.66\% and $11.39 \mathrm{~cm}$, respectively). Kaseem and AlAtrakchii (2006), in a study of the cutting of the Cotoneaster prostrata, showed that the wounded cutting was significantly increased by $65.27 \%$ compared with $60.76 \%$ for cutting without wounding. Abdulqader et al. (2017) studied the effect of wounding and IBA concentrations on the cuttings of olive trees (Olea europaea L.), where several concentrations of IBA $(0,2000$ and 4000) were used. The concentration of $2000 \mathrm{mg} \mathrm{L}^{-1}$ when coupled with wounding had the highest rooting rate of $87.78 \%$. In a research done by Radi and Hussein (2017) on the Acacia cyanophylla rooting and the effect of IBA and wounding. The cuttings that were wounded and treated with distilled water only had zero rooting rate. While the cuttings that were wounded and treated with auxin IBA concentrations (500, 1000 and $1500 \mathrm{mg}$ $\mathrm{L}^{-1}$ ) gave the percentage of rooting of 26.67, 46.67 and $46.67 \%$ sequentially and the number of leaves 12.88, 15.19 and 6.89 in respect order.

\section{MATERIALS AND METHODS}

The experiment was carried out in the plastic house of the Department of Horticulture and landscape Design, College of Agriculture and Forestry, University of Mosul, between January to June 2018. The cuttings were planted with sand soil. Insecticides and fungicides were then left for a week before planting.
Factors studied:

\section{Wounding:}

This involved the process of cutting at the bottom of cuttings as much as $1 \mathrm{~cm}$ deep using a sharp blade without reaching the inner bark.

\section{Rooting solutions:}

Seven different concentrations of auxin mixtures (NAA and IBA) were used with or without cinnamon powder extract concentrations were as follows:

1. Control treatment (50 $\mathrm{ml}$ ethyl alcohol + $50 \mathrm{ml}$ distilled water) (C1).

2. IBA at $750+\mathrm{NAA}$ at $750 \mathrm{mg} \mathrm{L}^{-1}$ (C2).

3. IBA at $1500+\mathrm{NAA}$ at $1500 \mathrm{mg} \mathrm{L}^{-1}$ (C3).

4. IBA at $750+\mathrm{NAA}$ at $750 \mathrm{mg} \mathrm{L}^{-1}+2 \mathrm{mg}$ $100 \mathrm{ml}^{-1}$ cinnamon extract (C4).

5. IBA at $750+\mathrm{NAA}$ at $750 \mathrm{mg} \mathrm{L}^{-1}+$ cinnamon extract at $4 \mathrm{mg} 100 \mathrm{ml}^{-1}$ (C5).

6. Cinnamon extract at $2 \mathrm{mg} 100 \mathrm{ml}^{-1}$ (C6).

7. Cinnamon extract at $4 \mathrm{mg} 100 \mathrm{ml}^{-1}$ (C7).

\section{Preparation of cinnamon extract solution:}

Cinnamon powder (30 g) was taken and then extracted by methanol alcohol (1 g powder:10 ml alcohol) using the Soxhlet for 3 hours at a temperature of $200{ }^{\circ} \mathrm{C}$ and then the solution was filtered with filter paper and then dried according to the method described by (Hamad, 2013). The required concentrations were prepared as following:

1. Cinnamon powder extract at $2 \mathrm{mg}$ was taken and dissolved in $50 \mathrm{ml}$ of ethyl alcohol and $50 \mathrm{ml}$ of distilled water.

2. Cinnamon powder extract at $4 \mathrm{mg}$ was taken and dissolved in $50 \mathrm{ml}$ ethyl alcohol and $50 \mathrm{ml}$ distilled water.

\section{RESULTS}

\section{The percentage of rooting of the cutting} (\%):

Table (1) shows that the process of wound defamation increased the rooting rate of the cutting to $38 \%$, but it was insignificant when compared with non-wound cutting which was $34.9 \%$. As for C4 rooting 
Table 1. Effect of wounding and rooting solutions on the rooting percentage (\%) of the bottle brush (Melaleuca viminalis L.).

\begin{tabular}{cccccccccc}
\hline $\begin{array}{c}\text { Wounding } \\
\text { situation }\end{array}$ & C1 & C2 & C3 & C4 & C5 & C6 & C7 & Effect of \\
wounding \\
\hline Without wound & $24.44 \mathrm{bc}$ & $17.77 \mathrm{c}$ & $31.11 \mathrm{bc}$ & $62.22 \mathrm{a}$ & $62.22 \mathrm{a}$ & $33.33 \mathrm{a}-\mathrm{c}$ & $42.22 \mathrm{a}-\mathrm{c}$ & $34.92 \mathrm{a}$ \\
& & & & & & & & \\
With wound & $51.11 \mathrm{ab}$ & $28.88 \mathrm{bc}$ & $53.33 \mathrm{ab}$ & $51.11 \mathrm{ab}$ & $40.00 \mathrm{a}-\mathrm{c}$ & $15.55 \mathrm{c}$ & $26.66 \mathrm{bc}$ & $38.09 \mathrm{a}$ \\
$\begin{array}{c}\text { Effect of rooting } \\
\text { solution }\end{array}$ & $37.77 \mathrm{ab}$ & $23.33 \mathrm{~b}$ & $42.22 \mathrm{ab}$ & $56.66 \mathrm{a}$ & $36.66 \mathrm{ab}$ & $24.44 \mathrm{~b}$ & $34.44 \mathrm{~b}$ & \\
\hline
\end{tabular}

C1: Control; C2: $750 \mathrm{mg} \mathrm{L}^{-1}$ IBA +750 $\mathrm{mg} \mathrm{L}^{-1} \mathrm{NAA}$; $3: 1500 \mathrm{mg} \mathrm{L}^{-1} \mathrm{IBA}+1500 \mathrm{mg} \mathrm{L}^{-1} \mathrm{NAA}$; C4: $750 \mathrm{mg}$

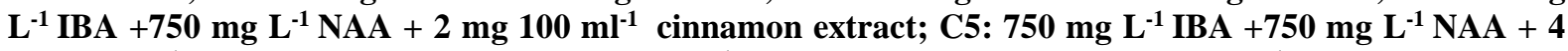

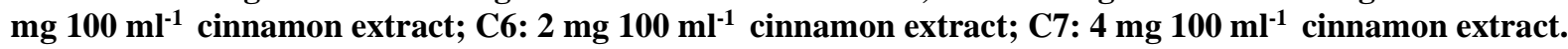

solution, the highest rooting percentage of $56.66 \%$ was recorded. The non-wound cutting was given in combination with the rooting solution C4 was $62.22 \%$. It is noticed from the Table that the process of wounding did not have a significant effect on the percentage of rooting in the treatment of the cutting rooting solutions, but had a clear effect in increasing the percentage of rooting for the comparison, which amounted 51.11\% compared to non-wound cutting (24.44\%).

\section{Number of leaves:}

Table (2) indicates that wounding of the cuttings led to an insignificant increase in the number of leaves on the cutting, reaching 9.51. As for the effect of rooting solutions, the rooting solutions did not affect the number of leaves when compared to the control (15.60). The interaction between the wounding process and the rooting solutions gave the highest value of the number of leaves in C4 solution without wounding (14.82) which was equal to C1 control with wounding (20.30) when compared with the remaining interactions.

\section{The length of vegetative growth $(\mathrm{cm})$ :}

Table (3) indicates that wounding of the cuttings did not increase the length of modern vegetative growth. As for the effect of rooting solutions, the rooting solution $\mathrm{C} 4$ give the highest value $(2.50 \mathrm{~cm})$ when compared with the rest of the solutions except $\mathrm{C} 1$ control $(1.90 \mathrm{~cm})$. With regards to the interaction, $\mathrm{C} 4$ solution regardless of the wounding situation, gave higher results when compared to some of the remaining combinations (Table, 3).

\section{The value of chlorophylls (SPAD):}

From Table (4) the non-wounded cuttings gave the highest value of 9.90 SPAD, the wounded cutting gave 6.57 SPAD. The effect of rooting solutions was insignificant where all rooting solution gave similar results except $\mathrm{C} 5$ which was less than C7. The overlap of the process wounding of cuttings with the solutions of rooting, gave an unclear trend except with C3 when coupled with un-wounded when cpmpared with C2, C5 and C6 when coupled with wounding (Table, 4).

\section{Fresh weight (FW) of the vegetative growth (g):}

Table (5) shows that the wound process of the cuttings was insignificant on FW increases of new vegetative growth. The rooting solutions gave similar trend to wounding. While the overlap of the wound process of the cutting with rooting solutions, showed that C3 when coupled with wounding gave the highest value (3.38 g) when compared to some other combinations (Table, 5). 
Table 2. Effect of wounding and rooting solutions on the leaf number of the bottle brush (Melaleuca viminalis L.).

\begin{tabular}{|c|c|c|c|c|c|c|c|c|}
\hline \multirow{2}{*}{$\begin{array}{l}\text { Wounding } \\
\text { situation }\end{array}$} & \multicolumn{7}{|c|}{ Rooting solutions } & \multirow{2}{*}{$\begin{array}{l}\text { Effect of } \\
\text { wounding }\end{array}$} \\
\hline & C1 & $\mathrm{C} 2$ & C3 & C4 & C5 & C6 & C7 & \\
\hline Without wound & $10.88 \mathrm{~b}$ & $2.15 \mathrm{~d}$ & 4.04 c d & $17.82 \mathrm{a}$ & $7.20 \mathrm{~b}-\mathrm{d}$ & $11.35 \mathrm{~b}$ & $6.17 \mathrm{~b}-\mathrm{d}$ & $8.52 \mathrm{a}$ \\
\hline With wound & $20.30 \mathrm{a}$ & 3.33 c d & $6.13 \mathrm{~b}-\mathrm{d}$ & 10.55 b c & $8.88 \mathrm{~b}-\mathrm{d}$ & 8.24 b-d & 9.15 b-d & $9.51 \mathrm{a}$ \\
\hline $\begin{array}{l}\text { Effect of rooting } \\
\text { solution }\end{array}$ & $15.60 \mathrm{a}$ & $2.74 \mathrm{~d}$ & $5.08 \mathrm{c} \mathrm{d}$ & $14.18 \mathrm{a} \mathrm{b}$ & $8.04 \mathrm{c}$ & $9.80 \mathrm{~b} \mathrm{c}$ & $7.66 \mathrm{c}$ & \\
\hline
\end{tabular}

C1: Control; C2: $750 \mathrm{mg} \mathrm{L}^{-1}$ IBA +750 $\mathrm{mg} \mathrm{L}^{-1} \mathrm{NAA}$; C3: $1500 \mathrm{mg} \mathrm{L}^{-1} \mathrm{IBA}+1500 \mathrm{mg} \mathrm{L}^{-1} \mathrm{NAA}$; C4: $750 \mathrm{mg}$ $\mathrm{L}^{-1} \mathrm{IBA}+750 \mathrm{mg} \mathrm{L}^{-1} \mathrm{NAA}+2 \mathrm{mg}^{100} \mathrm{ml}^{-1}$ cinnamon extract; C5: $750 \mathrm{mg} \mathrm{L}^{-1} \mathrm{IBA}+750 \mathrm{mg} \mathrm{L}^{-1} \mathrm{NAA}+4$

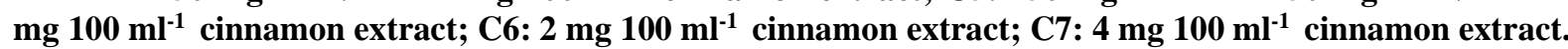

Table 3. Effect of wounding and rooting solutions on the length of vegetative growth $(\mathrm{cm})$ of the bottle brush (Melaleuca viminalis $\mathrm{L}$.).

\begin{tabular}{ccccccccc}
\hline $\begin{array}{c}\text { Wounding } \\
\text { situation }\end{array}$ & C1 & C2 & C3 & C4 & C5 & C6 & C7 & $\begin{array}{c}\text { Effect of } \\
\text { wounding }\end{array}$ \\
\hline Without wound & $1.10 \mathrm{a} \mathrm{b}$ & $0.42 \mathrm{~h}$ & $0.62 \mathrm{~d} \mathrm{~h}$ & $2.88 \mathrm{a}$ & $1.07 \mathrm{c}-\mathrm{h}$ & $1.46 \mathrm{c}-\mathrm{h}$ & $1.09 \mathrm{c}-\mathrm{h}$ & $1.24 \mathrm{a}$ \\
& & & & & & & & \\
With wound & $2.70 \mathrm{a} \mathrm{b}$ & $0.46 \mathrm{~d} \mathrm{~h}$ & $1.11 \mathrm{c}-\mathrm{h}$ & $2.11 \mathrm{a}-\mathrm{c}$ & $1.74 \mathrm{~b} \mathrm{c}$ & $1.53 \mathrm{c} \mathrm{d}$ & $1.22 \mathrm{c}-\mathrm{h}$ & $1.55 \mathrm{a}$ \\
& & & & & & & & \\
$\begin{array}{c}\text { Effect of rooting } \\
\text { solution }\end{array}$ & $1.90 \mathrm{a} \mathrm{b}$ & $0.44 \mathrm{~d}$ & $0.90 \mathrm{c} \mathrm{d}$ & $2.50 \mathrm{a}$ & $1.41 \mathrm{~b} \mathrm{c}$ & $1.50 \mathrm{~b} \mathrm{c}$ & $1.16 \mathrm{c}$ \\
\hline
\end{tabular}

C1: Control; C2: $750 \mathrm{mg} \mathrm{L}^{-1}$ IBA +750 $\mathrm{mg} \mathrm{L}^{-1}$ NAA; C3: $1500 \mathrm{mg} \mathrm{L}^{-1}$ IBA +1500 mg L L $^{-1} \mathrm{NAA}$; C4: $750 \mathrm{mg}$

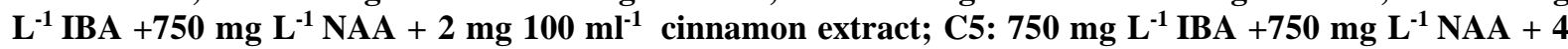

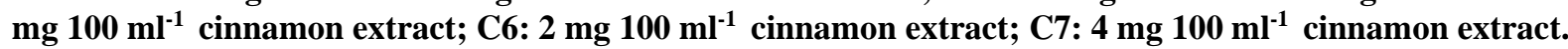

Table 4. Effect of wounding and rooting solutions on the value of chlorophyll (SPAD) of the bottle brush (Melaleuca viminalis $\mathrm{L}$.).

\begin{tabular}{|c|c|c|c|c|c|c|c|c|}
\hline \multirow{2}{*}{$\begin{array}{l}\text { Wounding } \\
\text { situation }\end{array}$} & \multicolumn{7}{|c|}{ Rooting solutions } & \multirow{2}{*}{$\begin{array}{l}\text { Effect of } \\
\text { wounding }\end{array}$} \\
\hline & C1 & C2 & C3 & C4 & C5 & C6 & C7 & \\
\hline Without wound & 5.93 a-c & $9.73 \mathrm{a}-\mathrm{c}$ & $14.60 \mathrm{a}$ & $9.60 \mathrm{a}-\mathrm{c}$ & $7.60 \mathrm{a}-\mathrm{c}$ & $10.44 \mathrm{a} \mathrm{b}$ & $11.45 \mathrm{a} \mathrm{b}$ & 9.90 a \\
\hline With wound & $11.01 \mathrm{a} b$ & $5.56 \mathrm{~b} \mathrm{c}$ & $6.00 \mathrm{a}-\mathrm{c}$ & $6.02 \mathrm{a}-\mathrm{c}$ & $1.65 \mathrm{c}$ & 5.66 b c & $10.14 \mathrm{a}-\mathrm{c}$ & $6.57 \mathrm{~b}$ \\
\hline $\begin{array}{l}\text { Effect of rooting } \\
\text { solution }\end{array}$ & 8.50 a b & $7.65 \mathrm{a} \mathrm{b}$ & 10.26 a b & $7.80 \mathrm{ab}$ & $4.62 \mathrm{~b}$ & $8.05 \mathrm{a} \mathrm{b}$ & 10.80 & \\
\hline
\end{tabular}


Table 5. Effect of wounding and rooting solutions on fresh weight of new vegetative growth (g) of the bottle brush (Melaleuca viminalis L.).

\begin{tabular}{|c|c|c|c|c|c|c|c|c|}
\hline \multirow{2}{*}{$\begin{array}{l}\text { Wounding } \\
\text { situation }\end{array}$} & \multicolumn{7}{|c|}{ Rooting solutions } & \multirow{2}{*}{$\begin{array}{c}\text { Effect of } \\
\text { wounding }\end{array}$} \\
\hline & $\mathrm{C} 1$ & $\mathrm{C} 2$ & C3 & C4 & C5 & C6 & C7 & \\
\hline Without wound & $0.66 \mathrm{a} \mathrm{b}$ & $0.74 \mathrm{ab}$ & $0.27 \mathrm{~b}$ & $3.01 \mathrm{ab}$ & 0.89 a b & $1.24 \mathrm{ab}$ & $0.24 \mathrm{~b}$ & $1.01 \mathrm{a}$ \\
\hline With wound & $2.13 \mathrm{a} \mathrm{b}$ & $1.55 \mathrm{a} \mathrm{b}$ & 3.38 a & $1.60 \mathrm{ab}$ & b a 0.76 & $0.38 \mathrm{~b}$ & $0.49 \mathrm{a} \mathrm{b}$ & $1.47 \mathrm{a}$ \\
\hline $\begin{array}{l}\text { Effect of rooting } \\
\text { solution }\end{array}$ & 1.39 a & $1.14 \mathrm{a}$ & $1.82 \mathrm{a}$ & $2.30 \mathrm{a}$ & $0.83 \mathrm{a}$ & $0.81 \mathrm{a}$ & $0.37 a$ & \\
\hline
\end{tabular}

6. Dry weight (DW) of the vegetative growth (g):

Table (6) shows that the non-wounded cutting gave the highest dry weight of the vegetative growth of the wounded cutting, which amounted $0.64 \mathrm{~g}$. The rooting solution C4 gave the highest weight (1.06 mg) and the same non-wounded cuttings solution, gave the highest dry weight which reached $(1.51 \mathrm{~g})$, while the comparison treatment of the wounded cutting gave a higher value of $(0.81 \mathrm{~g})$ when compared with the nonwounded cutting which reached $(0.45 \mathrm{~g})$.

\section{DISCUSSION}

Wounding on its own had no effect on most important parameters studied i.e rooting percentage, number of leaves, length of new vegetative growth on cuttings of bottle brush (Melaleuca viminalis, L.) plant. But, when wounding was coupled with a rooting solution that contained IBA and NAA both at $750 \mathrm{mg} \mathrm{L}^{-1}$ plus cinnamon extract (at 2 mg $100 \quad \mathrm{ml}^{-1}$ ) the abovementioned parameters were clearly increased when compared to most of the remaining treatments. With regards to the rooting solutions per se, the only clear-cut result was that the concentration of cinnamon at $4 \mathrm{mg} 100 \mathrm{ml}^{-1}$ on its own was inhibitory on the above-mentioned traits. Packs of fiber and sclereids cells outside the area of the formation of the adventitious roots, which may form a kind of mechanical or chemical disability of the division of cells and the exit of the roots incidental across that

Table 6. Effect of wounding and rooting solutions on dry weight of new vegetative growth (g) of the bottle brush (Melaleuca viminalis L.).

\begin{tabular}{|c|c|c|c|c|c|c|c|c|}
\hline \multirow{2}{*}{$\begin{array}{l}\text { Wounding } \\
\text { situation }\end{array}$} & \multicolumn{7}{|c|}{ Rooting solutions } & \multirow{2}{*}{$\begin{array}{l}\text { Effect of } \\
\text { wounding }\end{array}$} \\
\hline & C1 & C2 & C3 & C4 & C5 & C6 & C7 & \\
\hline Without wound & $0.45 \mathrm{a} b$ & $0.30 \mathrm{~b}$ & $0.18 \mathrm{~b}$ & $1.51 \mathrm{a}$ & $0.52 \mathrm{a} \mathrm{b}$ & $0.69 \mathrm{a} b$ & $0.15 \mathrm{~b}$ & $0.64 \mathrm{a}$ \\
\hline With wound & $0.81 \mathrm{a} b$ & $0.58 \mathrm{a} b$ & $1.47 \mathrm{a}$ & $0.61 \mathrm{a} b$ & $0.48 \mathrm{a} \mathrm{b}$ & $0.24 \mathrm{~b}$ & $0.28 \mathrm{~b}$ & $0.54 \mathrm{a}$ \\
\hline $\begin{array}{c}\text { Effect of rooting } \\
\text { solution }\end{array}$ & $0.63 \mathrm{a} \mathrm{b}$ & $0.44 \mathrm{ab}$ & $0.83 \mathrm{a} \mathrm{b}$ & $1.06 \mathrm{a}$ & $0.50 \mathrm{a} \mathrm{b}$ & 0.47 a b & $0.22 \mathrm{~b}$ & \\
\hline
\end{tabular}

C1: Control; C2: $750 \mathrm{mg} \mathrm{L}^{-1}$ IBA +750 $\mathrm{mg} \mathrm{L}^{-1} \mathrm{NAA}$; C3: $1500 \mathrm{mg} \mathrm{L}^{-1}$ IBA +1500 $\mathrm{mg} \mathrm{L}^{-1} \mathrm{NAA}$; C4: 750 mg

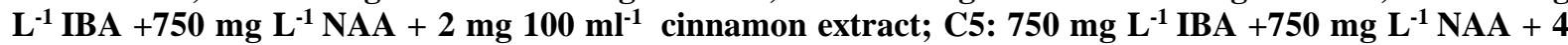

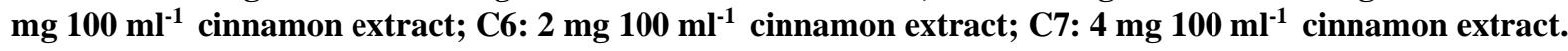




\section{Raghad L. Hameed and Asmaa M. Adil}

ring (Pontikis, 1979 and Sultan, 1974). This disability can be terminated be carrying out wounding which at the end leads to cell division and formation and appearance of adventitious root on cuttings. Hartmann et al. (1990) showed another reason for the response of cuttings to wounding saying that after the wounding, callus is formed and the roots develop, which are dense along the area of the wound. The use of IBA and NAA in the rooting solution at $750 \mathrm{mg} \mathrm{L}^{-1}$ with the addition of cinnamon at $2 \mathrm{mg} 100 \mathrm{ml}^{-1}$ led to increase the percentage of rooting. It is known that the auxins activate the process of cell division of root primordial which may be interpreted based on the speed of the accumulation of bitter rooting co-factor in the bases of the cuttings (Hartmann et al., 1990). Whereas Cinnamomum zeylanicum extract contains plant-stimulating substances and vitamins (Alush, 2009 and Sunarpi, 2012). The effect of the extract is a synergistic effect with growth regulators because it contains salts and vitamins.

\section{REFERENCES}

Abdulqader, S.M.; Abdulrhman, A.S. and Ibrahim, Z.R. (2017). Effect of wounding and different concentration of IBA on the rooting and vegetative growth of stem cutting of three olive cultivars (Olea europaea L). Kufa Journal for Agricultural Sciences, 2(9):225-203.

Abu Zeid, A.N. (2002). Cultivation and Production of Flowers and Ornamental Plants. Arabic House for Publishing and Distribution, Cairo, Egypt, 574 p.

Alush, B.M.; Hadeel, M. and Mushtaq, F.K. (2009). The use of wild dandelion extract Taraxacum officinala wigg as an alternative to some components of MS medium in the plantations of the plant of the tomato. Journal of the University of Kufa Life Sciences, 2(1):68-72.

Gunjan, S. and Anart, R.N. (2009). Influence of explants type and plant growth regulators on in vitro multiple shoots regeneration of laurel from Himalaya. Nature and Science, 7(9):1-7.

Hamad, S.F. (2013). Effect of cinnamon extract Cinnamomum zeylanicum in the rooting of the gardenia plant (Gardenia jasmenoides Ellis). Baghdad Journal of Science, 10(4):1102-1107.

Hartmann, H.T.; Kester, D.E. and Davies, F.T. (1990). Plant Propagation. Principle and Practices, $5^{\text {th }}$ edition. Prentice-Hall, International, Englewood Cliffs. New Jersey, 920 p.

Ibrahim, A.M. and Muhamad, S.H. (1991). Propagation Nurseries of Horticultural Crops (Fruits, Flowers, Ornamental Plants and Vegetables), $2^{\text {nd }}$ edition. Knowledge Facility, Alexandria, Egypt, $534 \mathrm{p}$.

Kaseem, G.Y and Al-Atrakchii, A.O. (2006). Propagation of Cotoneaster prostrata by stem cuttings. Mesopotamia Journal of Agriculture, 34(4):20-29.

Pontikis, C.A.; Mackenzie, K.A.D. and Howard, B.H. (1979). Establishment of initially un rooted stool shoots of M27 apple root stock. J. Hort. Sci., 54(1):7985.

Radi, I.M. and Hussein, K.A. (2017). Effect of the type of cutting and IBA and wounding in the root and growth of the cutting of the stem of the Acacia (Acacia cyanophylla). AL-Bahir Quarterly Refereed Journal for Natural and Engineering science, 6(10-11): 47-55.

Saladdin, S. (2015). Effect of cutting place, plant hormones and mechanical treatments on the rooting of the cutting. Tikrit University Journal of Agricultural Sciences, 15(2):92-100.

Salman, M.A. (1988). Reproduction of vegetable plants. Directorate of the House of Books for Printing and Publishing, University of Mosul, Iraq.

Sultan, S.M. (1974). Studies on Vegetative Propagation of Some Nursery Stocks. Ph.D. Thesis, Wye College., Univ. of London, UK.

Sunarpi, A.J.; Kurnianingsih, R.; Indahjulisaniah, N. and Nikmatullah, A. (2012). Effect of seaweed extract on growth and yield of rice plant. Bioscience. 2(2):73-77. 
تأثير التجريح والاوكسينات ومستخلص القرفة في تجذير وصفات النمو الخضري لعقل نبات فرشة البطل Melaleuca viminalis $\mathbf{L}$.

\author{
رغد لؤيد حميد و أسماء محمد عادل \\ قسم البستنة و هندسة الحدائق، كلية الزر اعة و الغابات، جامعة الموصل، الموصل، جمهورية العراق.
}

أُجريت هذه الدراسة على نبات فرشة البطل . Melaleuca viminalis L في البيت البلاستيكي التابع لقسم البستنة

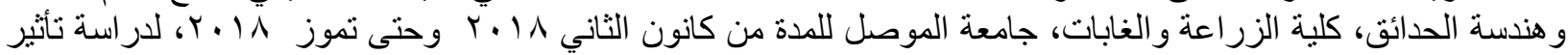

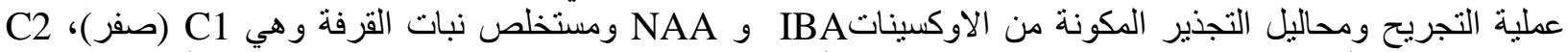

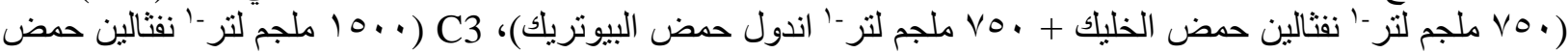

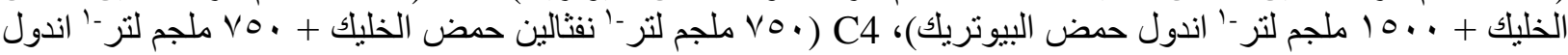

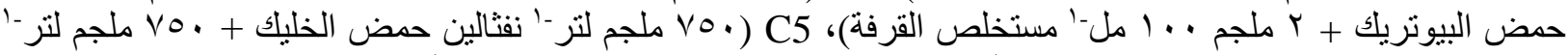

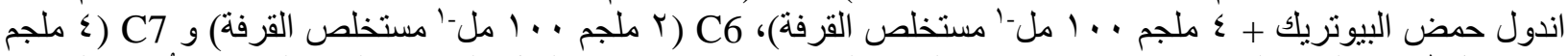

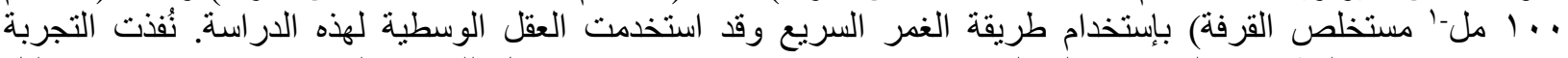

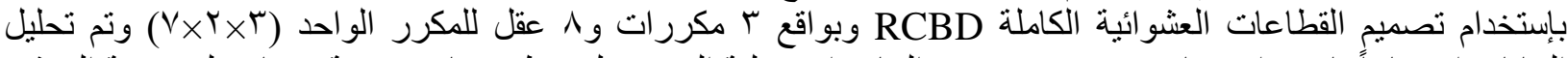

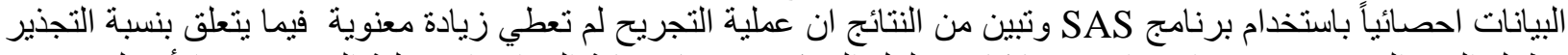

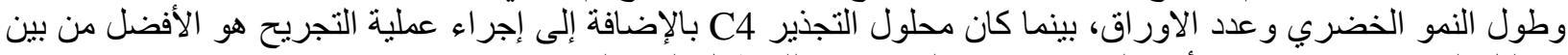

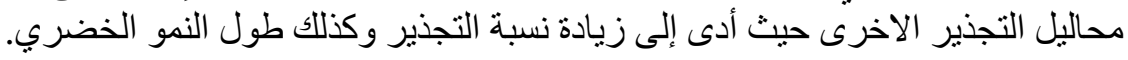

